\title{
DESIGN AND MANUFACTURE OF A COOKING UNIT FOR PRODUCING POULTRY BY-PRODUCTS MEAL AS NON-TRADITIONAL FEED
}

\author{
M. M. A. El-Sharabasy ${ }^{1}$, M. M. Badr' ${ }^{2}$ M. E. Mostafa ${ }^{3}$ and Amira A.M. Amin ${ }^{4}$
}

\section{ABSTRACT}

Test Experiments were carried out to design, manufacture and evaluate the performance of a cooking unit used for rendering poultry abattoir residues (intestines and legs residues) and investigate the effect of using these byproducts in feeding Nile tilapia fish. The performance of the manufactured cooker was studied under the following parameters: Three different poultry abattoir treatments were $100 \%$ intestines, $50 \%$ legs $+50 \%$ intestines and 100\% legs under four different agitating speeds 20, 30, 40 and 50 rpm and was evaluated taking into consideration the following indicators: productivity, cooking efficiency, total losses, specific energy and criterion costs through the first experiment. With regard to the second experiment was aimed to investigate the effect of different levels of poultry by-product meal on the feed utilization and whole-body composition of Nile tilapia fish. Growth performance was studied taking into consideration both of feed efficiency ratio and protein efficiency ratio. The results reveal that the highest values of machine productivity and cooking efficiency were $(52.30$ $\mathrm{kg} . \mathrm{h}^{-1}$ and $\left.97.90 \%\right)$, while the lowest values of the total losses and criterion cost were $\left(2.10 \%\right.$ and $\left.1500 \mathrm{LE} . \mathrm{Mg}^{-1}\right)$, respectively under agitating speed of 40 rpm with adjusting vapor pressure on 2 bar using $50 \%$ intestines $+50 \%$ legs residue. Furthermore, the obtained results show that there is no difference in growth performance and feed utilization between Nile tilapia fish when feeding on diets have 25 and $50 \%$ of poultry by-product meal i.e. 75 and $50 \%$ of fish meal.

\section{INTRODUCTION}

lthough food is essential in that it supplies the nutrients necessary to
sustain life, it must first be consumed in order to supply the needed
nutrients.

\footnotetext{
${ }^{1}$ Vice Dean and Prof. of Agric. Eng., Fac. of Agric., Zagazig Univ., Egypt.

${ }^{2}$ Assist. Prof. of Agric. Eng., Fac. of Agric., Damietta Univ., Egypt.

${ }^{3}$ Prof. of Fish Production, Central Lab. Aqua. Res., Agric. Res. Cent., Egypt.

${ }^{4}$ Assist. Researcher, Central Lab. Aqua. Res., Agric. Res. Cent., Egypt.
} 
Thus, food must not only be pleasing in taste, aroma, consistency and appearance to make it palatable but it must also satisfy the nutritional requirements and aesthetic needs of consumers in order to fulfil its lifesustaining role.

Meat, poultry and fish products must meet the same requirements as other foods in providing not only nutritionally adequate, but palatable and acceptable products to the diet of humans, Pearson (1994). In Egypt, the relative high price of animal protein created a great demand towards fishes, which provides protein of high digestibility and nutritive value closely resembling that of animal protein on basis of their essential amino acids. Moreover, the relative cheaper price of fish and the rapid growth in domestic demand for fish and seafood products should prompt all to improve this sector in all directions. Animal protein is the most valuable component of diet. Fish, as a source of protein for human consumption, is essential to help considerably in correcting the state of malnutrition in such circumstance, which is topographically situated alongside great areas of fresh and marine waters including canals and inland lakes. Fish meal is the major protein source in fish diet because it builds the natural proteins of fish. Fish meal is not only expensive but also was difficult to be in steady current competition between fish and poultry in one side and mankind in other side. For these reasons, nutritionists try to replace part of fish meal as animal protein by another unconventional protein sources. Davis (1989), stated that, the continuous process is merely an extension of the batch process and has some more practical advantages as far as capacity is concerned. These two processes involve hydrolyzing feathers with steam at high moisture levels and employs thermal drying to reduce the moisture content of the final product. Kumar (1989), reported that, wet rendering is a process in which the raw material and added water are subjected to direct high steam pressure in a wet rendering vessel. A wet rendering process may be carried out in batch or continuous formats, and in horizontal or vertical vessels. El Boushy et al. (1990a), reported that, wastes from poultry slaughter are blood, feathers and offal (viscera, heads, and feet), and if collected separately can be processed into blood meal, hydrolized feather meal, poultry offal meal, and fat, respectively. A large proportion consists of poultry feathers which are keratinous proteins, as well as offal. Since feather protein in its natural state is very poorly digested by monogastric animals, various methods have been 
developed for processing these keratinous proteins into a more digestible form. The following practices are generally used in processing poultry byproducts. A large proportion of the water is evaporated in a dry-rendering cooker to hydrolize, sterilize and reduce the material to about $8 \%$ moisture either in the same cooker or in a separate dryer. The dehydrated material is then pressed to remove excess fat so the rendered material has a fat content of about $10 \%$. Finally, the product is ground to a size small enough to pass through 8-12 mesh screens. El Boushy et al. (1990b), reported that, there are two methods for producing by-products from poultry wastes as following: (a) Batch cooker: which usually processed in dry-rendering cookers of $(1,000-$ $15,000 l$ ) content. These cookers are steam jacketed, with horizontal shaft agitators, and have a dome for loading and a bottom-front opening for discharge. They are generally designed for steam pressures of (414-850 kPa) and charged with an internal pressure of (207-350 kPa). Internal pressures as low as $138 \mathrm{kPa}$ and as high as $414 \mathrm{kPa}$ have also been used. The processing time is 4-7 $\mathrm{h}$ from the time the cooker is closed until it is opened to discharge. The critical point appears to be that the entire charge should be maintained at the equivalent of $207 \mathrm{kPa}$ for at least 15 minutes. (b) Continuous processing: in this method the following steps are employed: feathers are fluffed to facilitate their transport through the intake lock of a pressurized vessel; and the feathers are hydrolyzed at a high moisture content (60-80\%) inside the pressurized vessel, which is continuously operated through intake and outlet locks. The average residence time is (6-15 min) and the pressure is about (483-690 $\mathrm{kPa}$ ). The feathers are subsequently subjected to a first drying stage of the liquid slurry discharged from the hydrolized feathers to a moisture content of about 40\%. EGAFS (1992), found that, the time required to complete the rendering process depends greatly on the temperature and air pressure inside the system. As the air pressure and temperature increase, the time to complete the rendering process decreases. For example, the same material that that requires a process time of about (3.5 h) at $\left(125^{\circ} \mathrm{C}\right)$ may only require $(35 \mathrm{~min})$ under pressure $(2 \mathrm{bar})$ at $\left(141^{\circ} \mathrm{C}\right)$. Swan (1992), mentioned that, transferring the by-products of poultry slaughtering to a mixed poultry meal (soft offal, blood, feathers and dead birds in their natural proportion), rendering is taking place. Rendering refers to different heating applications to remove fat from meat. Steffens (1994), mentioned that, nutrition plays an important role in intensive fish production, 
depending upon the type of feed availability and its cost. To minimize the cost of feed for tilapia and other cultured fish species, emphasis is bending laid on research into use of agro-industrial by-product to replace expensive protein sources as well as to reduce hazard of pollution resulting from these waste products. Prokop (1996), found that, the factors such as time, temperature, particle size, liquid level, and speed of the rotor in cylindrical tanks (defined as revolutions per minute or RPM) directly impact the quality and quantity of finished rendered products. Factors such as electrical loads in amperes for certain equipment, control valve settings, and equipment on/off status are considered indirect parameters. In modern rendering operations, computerized systems monitor and provide instantaneous indications of all of the above. Pulsa (1996), indicated that wet rendering process is done at temperature degree of $133^{\circ} \mathrm{C}$ and cooking time of $20 \mathrm{~min}$ or an alternative heat treatment is required for high-risk materials used for animal feed or as an intermediate product for the manufacture of organic fertilizer or other derived products. In addition, rendering produces fat, which may be used for animal feed, in chemical industry products, or burned as fuel. Slaughterhouse by-products are preserved with formic acid as it has good source of proteins and vitamins and are used as animal feed. Hertrampf and Pascual (2000), indicated that poultry by-product meal is golden to medium brown in color with fresh poultry odors. Ockerman (2000), indicated that although wet rendering can produce good-quality tallow, this system is no longer used because of its high energy consumption, loss of meal (up to $25 \%$ in wastewater), and adverse effects on fat quality. Taylor (2000), stated that, the conventional rendering processes do not inactivate prion proteins; but it can reduce their infectivity. He added that, complete inactivation will be achieved, when materials are cooked at $132^{\circ} \mathrm{C}\left(270^{\circ} \mathrm{F}\right)$ at approximately $3 \mathrm{bar}$ (45psi) for $4.5 \mathrm{~h}$. UKDEFRA (2000), reported that, the batch and continuous rendering systems use indirect steam in jacketed vessels. Generally, continuous ones are equipped with automatic controls for both time and temperature. Continuous systems also generally offer greater flexibility, allowing a wider range of time and temperature combinations for cooking raw materials. Environmental Protection Agency (2002), stated that, the wet rendering method uses direct pressurized steam to cook carcasses, the relatively "newer" method of dry rendering cooks ground carcasses indirectly in their own fat while contained in a horizontal, steam-jacketed 
vessel equipped with an agitator. In both methods, the final temperature of the cooker that ranging from 120 to $135^{\circ} \mathrm{C}$ destroys harmful pathogens and produces usable end products such as meat, feather, bone, and blood meal that can be used in animal feeds. He added that, batch cookers consist of steam-jacketed, cylindrical vessels equipped with revolving agitators, which facilitate further break down of fatty tissues. In the first stage, the raw material from the receiving bin is conveyed to a crusher to reduce its size to small pieces for efficient cooking process. Cookers are heated at normal atmospheric pressure to around $100^{\circ} \mathrm{C}$ until the moisture is driven off through vents in the form of steam and hence the temperature rises to (121$135^{\circ} \mathrm{C}$ ) For cooking process, which normally takes up 2-3 hours, the tallow is decanted off and the solids are emptied from the cooker.

\section{The objectives of the present study are to:}

1- Design and manufacture of a cooking unit to produce by-product from poultry residues for fish nutrition; 2- Determine some parameters affecting the performance of the manufactured cooking unit and 3- Evaluate the effect of using by-product meal for nutrition Nile tilapia.

\section{MATERIALS AND METHOD}

The first experiment was carried out through the year of 2017 at Department of Agricultural Engineering, Faculty of Agriculture, Zagazig University to design, manufacture and evaluate the performance of a batch cooker for producing poultry by-products meal. As well as the second experiment was executed at Production and Aquaculture System Department of Central Laboratory for Aquaculture Research, Abbassa, Abou Hammad, Sharkia Governorate to investigate the effect of different levels of poultry by-product meal on the performance tilapia fish.

\subsection{MATERIALS:}

\subsubsection{Raw material and fish:}

Two different kinds of poultry abattoir residues were used: intestines and legs residues. All male Nile tilapia Oreochromis niloticus fingerlings were obtained from fish hatchery, Central Laboratory for Aquaculture Research, Abou-Hammad, Sharkia.

\subsubsection{Manufactured cooker:}

A manufactured cooker as shown in Fig. (1) and Photo (1) consists of the frame, a steam jacketed vessel, mixing shaft, electric motor and gear box. It is a horizontal cylindrical steam jacketed vessel. 


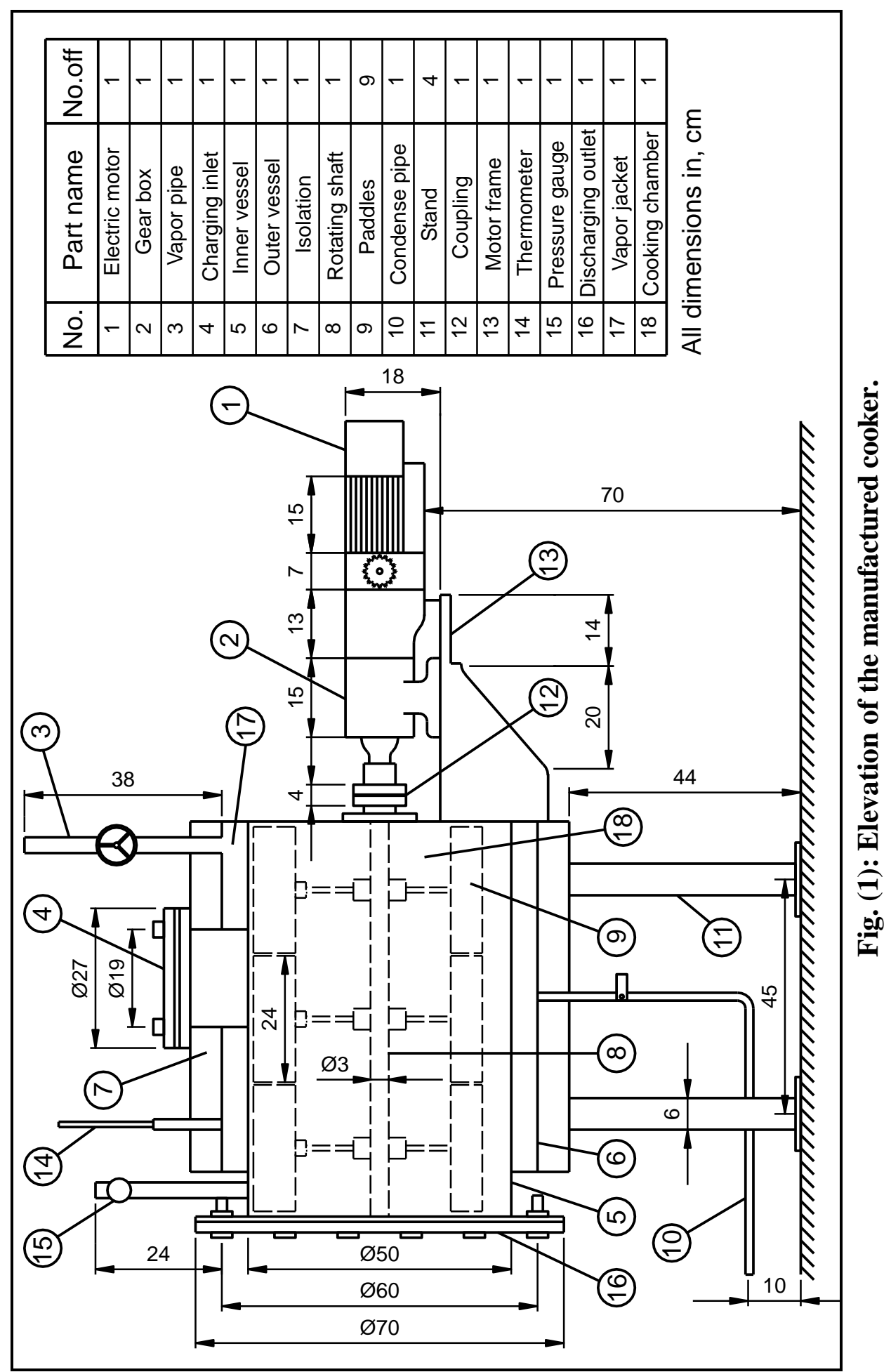




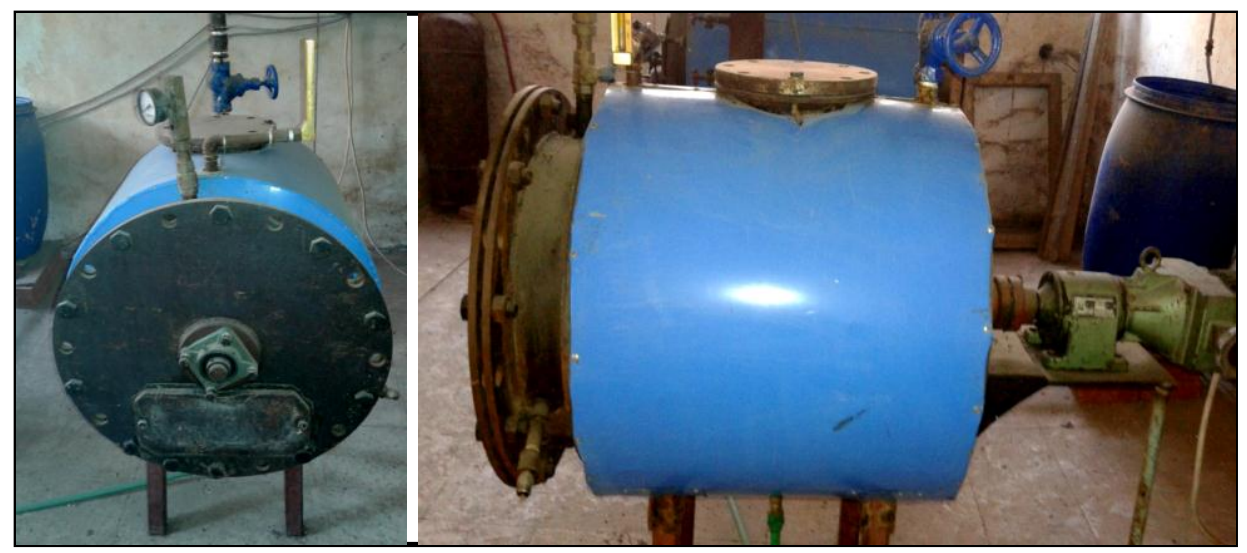

Photo (1): The manufactured cooker.

In the center of the vessel, the turning shaft was installed. This shaft is driven by an electric motor through a gear box at about $120 \mathrm{rpm}$. As the shaft turns, the paddles stir the material in the cooker during treatment of poultry abattoir residues. Steam is applied to the jacket through a steam line from the boiler header at temperature degree of $125^{\circ} \mathrm{C}$. Steam traps are on the underside of the cooker so as the steam turns to condensate, it is automatically drained. At the bottom of the front of the cooker there is an under-loading door. When the door is opened, the contents of the cooker empty into a percolator basket, in which the cooker material stands while the excess oil drains into a trough.

\subsection{METHODS:}

Abattoir poultry residues rendering for sterilized meat meal are an essential part of poultry dressing operations. Poultry dressing results in waste which is about $30 \%$ of bird weight. The whole waste resulting from treatment is cooked under high heat and converted into a sterilized meal where, the cooking process is done in installments. This meal made from poultry residues comprises of 45-55\% protein, 15-25\% moisture and 25-35\% fat.

\section{Experiments are divided into two parts:}

\subsubsection{The first experiment:}

The first experiment was conducted to evaluate the performance of the manufactured cooker and select optimum operating parameters suits the rendering process for each residue. Three different poultry abattoir treatments were used in this investigation are (100\% intestines, R1); (50\% intestines $+50 \%$ legs, R2) and (100\% legs, R3). The performance of the cooking unit was experimentally evaluated under four different agitating speeds of (20, 30, 40 and $50 \mathrm{rpm})$. 


\subsubsection{The second experiment:}

It was feeding experiment, which was carried out at the wet lab of Production and Aquaculture System Department in Central Laboratory for Aquaculture Research. This experiment aimed to investigate the effect of different levels of poultry by-product meal obtained from the initial experiment on the performance, feed utilization, whole body composition of Nile tilapia.

\subsubsection{Design of rendering cooker:}

The rendering cooking unit was designed with great interest because of tearing pressure on vessel means a blast, which may reason serious damage. According to the final construction, the pressure vessel may be classified as closed end in this case, longitudinal stresses in addition to circumferential stresses are induced. Consequently, the material of pressure vessel must be supported adequately under extreme operating condition.

\subsubsection{The outer vessel design:}

Regarding to the thin cylindrical vessel subjugated to internal pressure. A tensile stress action in a trend tangential to the perimeter named circumferential stress i.e. it is a tensile stress on the cylindrical vessel, as shown in Fig. (2).



(A):View of cylindrical vessel.

(B): Cross-section of cylindrical vessel.

Fig. (2): Effect circumferential stress on cylindrical shell.

Where: $p=$ Intensity of internal pressure.

$\mathrm{d}=$ Internal diameter of the cylindrical vessel.

$1=$ Length of the cylindrical vessel.

$\mathrm{t}=$ Thickness of the cylindrical vessel.

$\sigma_{\mathrm{t} 1}=$ Circumferential stress for the material of the cylindrical vessel.

The total force acting on a longitudinal section, $\mathrm{F}_{\mathrm{L}}$ along the diameter $\mathrm{X}-\mathrm{X}$ of the vessel can be calculated from the following equation:

$$
\mathrm{F}_{1}=\mathrm{p} \times \mathrm{d} \times 1
$$


For calculating the total resisting force, Q acting on the cylindrical vessel walls as follows:

$$
\mathrm{Q}_{1}=\sigma_{\mathrm{t} 1} \times 2 \mathrm{t} \times 1
$$

By balance between $\mathrm{F}$ and $\mathrm{Q}$ can be obtained the following relationship:

$$
\mathrm{Q}_{1}=\mathrm{F}_{1} \quad \& \quad \sigma_{\mathrm{t} 1} \times 2 \mathrm{t} \times \mathrm{l}=\mathrm{p} \times \mathrm{d} \quad \therefore \mathrm{t}=\frac{\mathrm{p} \times \mathrm{d}}{2 \sigma_{\mathrm{t} 1}}
$$

In constructing pressure, vessel welded joint is used in connecting together the sides of steel sheet. Therefore, efficiency of the longitudinal welded joint, $\eta$ must be taken into consideration. In this case, the wall thickness of the cylindrical vessel can be calculated from the follows equation:

$$
\mathrm{t}=\frac{\mathrm{p} \times \mathrm{d}}{2 \sigma_{\mathrm{t} 1} \times \eta}
$$

\subsubsection{Longitudinal stress:}

Fig.(3) is illustrated a closed cylindrical vessel which subjected to an internal pressure. A tensile stress affecting in the direction of the center is called longitudinal stress, $\sigma_{t 2}$ it is a stress acting on the transverse section $Y-Y$ or on the ends of the cylindrical vessel.

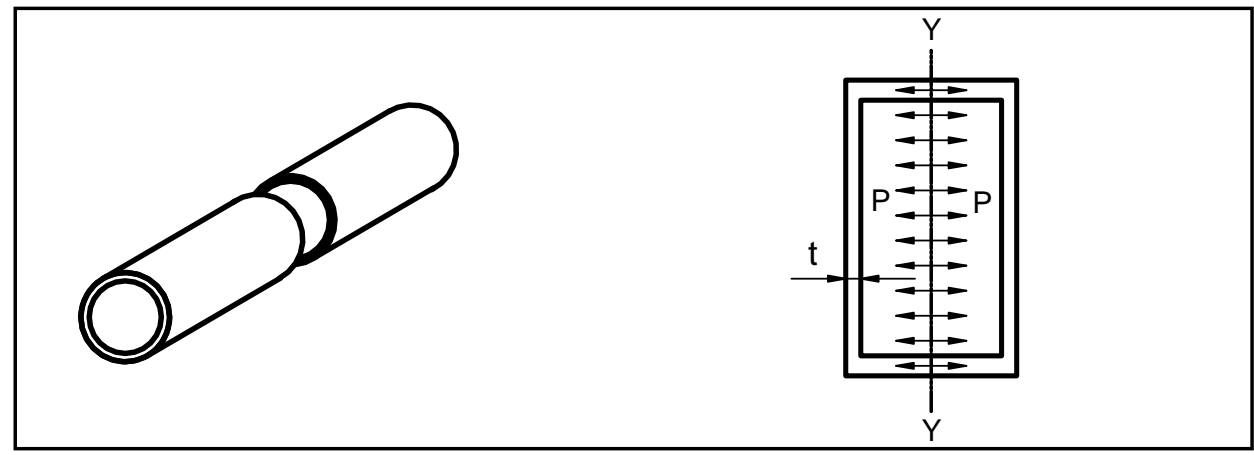

(A): View of cylindrical vessel.

(B): Cross-section of cylindrical vessel.

Fig. (3): Effect of longitudinal stress on cylindrical vessel.

$$
\begin{aligned}
& \because \mathrm{F}_{2}=\mathrm{p} \times \frac{\pi}{4} \mathrm{~d}^{2} \& \quad \mathrm{Q}_{2}=\sigma_{\mathrm{t} 2} \times \pi \mathrm{d} . \mathrm{t} \& \quad \because \quad \mathrm{Q}_{2}=\mathrm{F}_{2} \\
& \therefore \mathrm{p} \times \frac{\pi}{4} \mathrm{~d}^{2}=\sigma_{\mathrm{t} 2} \times \pi \mathrm{d} . \mathrm{t} \quad \therefore \quad \mathrm{t}=\frac{\mathrm{p} \times \mathrm{d}}{4 \times \sigma_{\mathrm{t} 2} \times \eta}
\end{aligned}
$$

From the previous equations, it can be concluded that the design of a pressure cylindrical vessel must be depended on the maximum stress, so, the wall thickness of the cooking unit can be calculated as follows: 


$$
\mathrm{t}=\frac{6 \times 10^{5} \times 0.5}{2 \times 35 \times 10^{6} \times 0.80}=5.36 \times 10^{-3} \mathrm{~m}=6 \mathrm{~mm}
$$

\subsubsection{Diets preparation and feeding regimen:}

Table (1) shows the four different levels of poultry by-product meal were used in the experimental diets: 25, 50, 75, 100\% replacing with fish meal compared with a control diet. In this study, the dry ingredients of each diet were thoroughly mixed and $100 \mathrm{ml}$ of water was added per kg diet thereafter, the mixture (ingredients and water) was blended using blender to make a paste of each diet.

Table (1): Composition and chemical analysis of the experimental diets.

Feed ingredients

\begin{tabular}{lccccc}
\hline Fish meal (72\%) & 20 & 15 & 10 & 5 & 0 \\
Poultry by-products & 0 & 10 & 15 & 20 & 25 \\
Yellow corn & 22 & 17 & 17 & 17 & 17 \\
Soybean meal (44\%) & 30 & 30 & 30 & 30 & 30 \\
Gluten & 10 & 10 & 10 & 10 & 10 \\
Rice bran & 12 & 12 & 12 & 12 & 12 \\
Vegetable oil & 3 & 3 & 3 & 3 & 3 \\
Vit. \& Min. mixture1 & 3 & 3 & 3 & 3 & 3 \\
Sum & 100 & 100 & 100 & 100 & 100 \\
\hline \multicolumn{5}{c}{ Chemical composition of the experimental diets } \\
\hline $\begin{array}{c}\text { Crude protein }(\mathrm{CP}) \\
\text { Ether extract (EE) }\end{array}$ & 30.2 & 30.19 & 30.13 & 29.8 & 29.73 \\
Crude fibre (CF) & 8.09 & 8.19 & 8.10 & 8.20 & 8.17 \\
(NFE) & 9.33 & 10.22 & 10.10 & 10.24 & 9.82 \\
Ash & 48.61 & 46.72 & 47.94 & 48.03 & 47.97 \\
Pelleting of each diet was carried out by passing the blended mixture through \\
laboratory pellet machine. The resulting wet pellets were dried at room \\
temperature for two days. The diets were stored in plastic bags in a \\
refrigerator at $-2{ }^{\circ} \mathrm{C}$ until use. Experimental diets were formulated to meet \\
the requirement of Nile tilapia fingerlings according to NRC, (1993). At the \\
beginning of experimental period a fish sample was taken for whole body \\
composition analysis. Also, the tested diets and whole-fish body from each \\
treatment at the end of the experiment were analyzed in triplicate samples to \\
determine moisture, crude protein, crude fat, crude fiber, nitrogen free extract \\
and ash according to the standard methods of AOAC, (1990).
\end{tabular}

\section{Experimental diets}

Diet-1 Diet-2 $\quad$ Diet-3 Diet-4 Diet-5

Pelleting of each diet was carried out by passing the blended mixture through laboratory pellet machine. The resulting wet pellets were dried at room temperature for two days. The diets were stored in plastic bags in a refrigerator at $-2{ }^{\circ} \mathrm{C}$ until use. Experimental diets were formulated to meet the requirement of Nile tilapia fingerlings according to NRC, (1993). At the beginning of experimental period a fish sample was taken for whole body composition analysis. Also, the tested diets and whole-fish body from each treatment at the end of the experiment were analyzed in triplicate samples to and ash according to the standard methods of AOAC, (1990). 


\subsection{MEASUREMENTS AND DETERMINATIONS:}

Evaluation of the performance of the batch cooker for producing poultry byproducts meal was based on the following indicators:

\subsubsection{Cooking unit productivity:}

Batch cooker productivity, $\mathrm{Cp}$ was determined by the following equation:

$$
C_{p}=\frac{W_{p}}{t}
$$

Where: $\mathrm{W}_{\mathrm{p}}=$ product weight, $\mathrm{kg}$ and $\mathrm{t}=$ the time consumed in cooking operation, $\mathrm{h}$.

\subsubsection{Cooking efficiency:}

Cooking efficiency, Ce was estimated during cooking process which can be calculated using the following equation:

$$
C_{e}=\frac{W_{c}}{W_{t}} \times 100
$$

Where: $\mathrm{W}_{\mathrm{C}}=$ final product weight cooked well and $\mathrm{W}_{\mathrm{t}}=$ total weight of discharging outlet, $\mathrm{kg}$.

\subsubsection{Required power:}

The required power estimated from the following formula:

$$
\mathrm{P}=\sqrt{3} \times \cos \varphi \times \mathrm{I} \times \mathrm{V}
$$

Where: $\mathrm{P}=$ required power, $\mathrm{kW}, \cos \varphi=0.7, \mathrm{I}=$ current intensity, Ampere,

$$
\mathrm{V}=\text { Voltage, volte. }
$$

\subsubsection{Specific energy:}

Specific energy in kW.h.Mg ${ }^{-1}$ was calculated using the following equation:

$$
\mathrm{S}_{\mathrm{e}}=\frac{\mathrm{P}}{\mathrm{C}_{\mathrm{p}}}
$$

\subsubsection{Criterion cost:}

The criterion cost, C.C required for the cooking operation was estimated using the following equation:

$$
\text { C.C }=\text { O.C }+ \text { L.C }
$$

Where: O.C $=$ operating cost, and L.C $=$ losses cost, L.E. $\mathrm{Mg}^{-1}$.

$$
\text { O.C }=\frac{\mathrm{H} . \mathrm{C}}{\mathrm{C}_{\mathrm{p}}}
$$

The hourly cost, H.C required for the cooking unit was estimated using the fixed costs and variable costs, L.E.h ${ }^{-1}$. 


\subsubsection{Feed conversion ratio:}

One of parameters that used to determine the value of nitration for providing the necessary food amount required for one unit of growth. A lower value indicates an improved outcome. Feed conversion ratio, FCR was calculated according to Ponganeerat and Watanabe, (1991) by the equation:

$$
\mathrm{FCR}=\frac{\mathrm{FI}}{\mathrm{WG}}
$$

Where: $F I=$ feed ingested and $W G=$ weight gain, $g$.

\subsubsection{Protein efficiency ratio:}

Protein efficiency ratio, PER is probably the most widely method used for valuating protein quality in fish. Whereas, can be measured by the following equation according to NRC, (1993):

$$
\mathrm{PER}=\frac{\mathrm{WG}}{\mathrm{PI}}
$$

Where: PI = Protein ingested, $\mathrm{g}$.

\section{RESULTS AND DISCUSSION}

The obtained results related to the first and second experiments will be discussed under the following items:

\subsection{Influence of agitating speed on productivity and cooking efficiency at different kinds of poultry abattoir residues:}

Representative values of productivity and cooking efficiency versus agitating speed at different kinds of poultry abattoir residues are given in Fig. 4. With regard of $100 \%$ intestines, $\mathrm{R}_{1}$ results show that increasing agitating speed from 20 to $50 \mathrm{rpm}$ increasing productivity from 55.10 to $65.80 \mathrm{~kg} \cdot \mathrm{h}^{-1}$. Obtained results also show that increasing agitating speed from 20 to $30 \mathrm{rpm}$ increased cooking efficiency from 95.80 to $96.50 \%$ while increasing speed from 30 to $50 \mathrm{rpm}$ decreased efficiency from 96.50 to $95.70 \%$ under the same previous conditions. In relation to (50\% intestines $+50 \%$ legs), $\mathrm{R}_{2}$ obtained results show that increasing agitating speed from 20 to $50 \mathrm{rpm}$ increased productivity from 46.50 to $52.30 \mathrm{~kg} \cdot \mathrm{h}^{-1}$. On the other hand, results show that increasing speed 20 to $40 \mathrm{rpm}$ increased cooking efficiency from 96.60 to $97.90 \%$ while increasing speed from 40 to $50 \mathrm{rpm}$ decreased efficiency from 97.90 to $96.40 \%$. Regarding $100 \%$ legs, $\mathrm{R}_{3}$, obtained results show that increasing speed from 20 to $50 \mathrm{rpm}$ increasing productivity from 31.40 to $44.20 \mathrm{~kg} \cdot \mathrm{h}^{-1}$. 


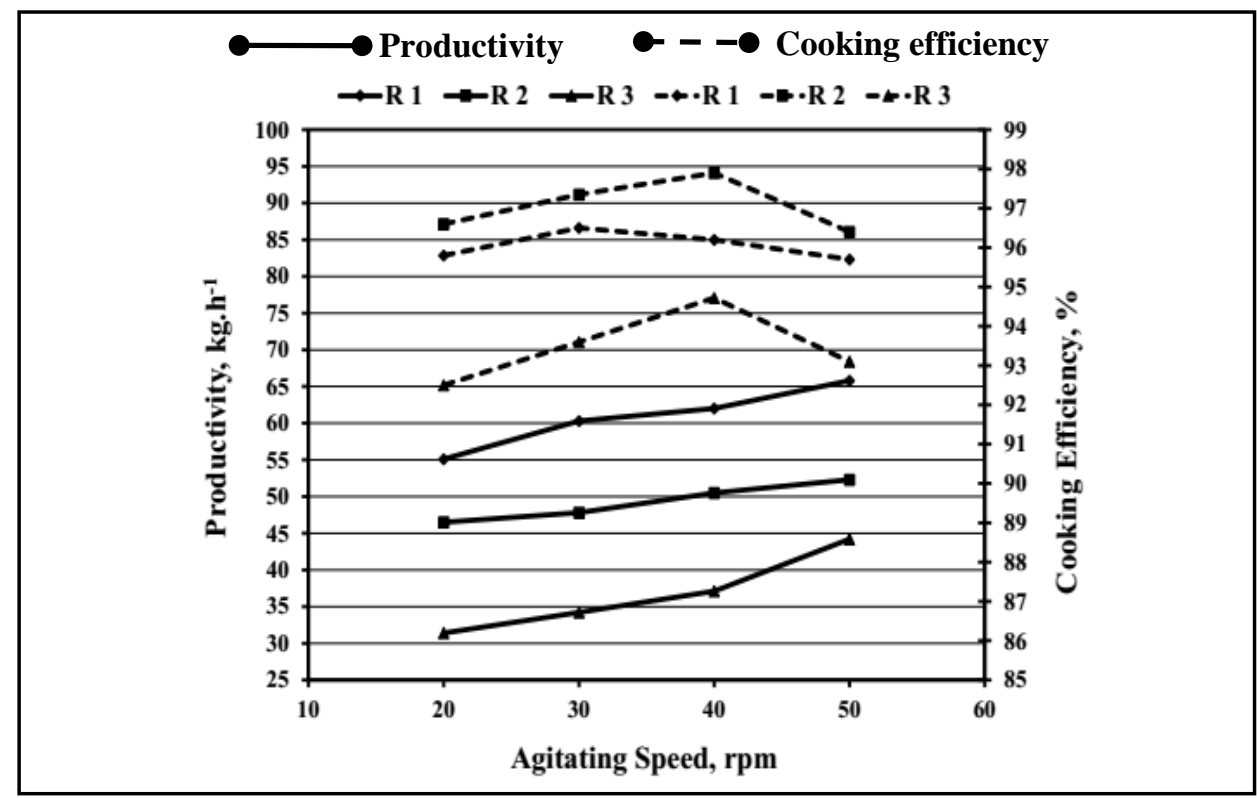

Fig. (4): Effect of agitating speed on productivity and cooking efficiency. Also results indicated that increasing agitating speed 20 to $40 \mathrm{rpm}$ increased cooking efficiency from 92.50 to $94.72 \%$ while increasing speed from 40 to $50 \mathrm{rpm}$ decreased efficiency from 94.72 to $93.10 \%$ under the same previous conditions and at constant vapor pressure of 2 bar. The cooking unit productivity increased by increasing agitating speed due to the decrease in time required for the cooking process at the same weight unit. Furthermore, the increasing of the agitating speed led to breaking raw materials during the rendering process. Higher values of speed more than the optimum value tend to decrease cooking efficiency due to low shredding efficiency for poultry residues. Beside that, lower values of mechanical agitator speed less than the optimum value tend to decrease cooking efficiency because of the decrease in friction between the parts of the raw material during the agitating process.

\subsection{Influence of agitating speed on total losses and specific energy at different kinds of poultry abattoir residues:}

Representative values of total losses and specific energy versus agitating speed at different kinds of poultry abattoir residues is given in Fig. 5. Relating to $R_{1}$, obtained results show that increasing speed from 20 to 30 rpm decreased total losses from 4.20 to $3.50 \%$ while increasing speed from 30 to $50 \mathrm{rpm}$ increased total losses from 3.50 to $4.30 \%$. Whereas increasing agitating speed from 20 to $50 \mathrm{rpm}$ decreased specific energy from 26.68 to 
22.34 kW.h. $\mathrm{Mg}^{-1}$ under the same previous conditions. Regarding $\mathrm{R}_{2}$, obtained results show that increasing speed 20 to $40 \mathrm{rpm}$ decreased total losses from 3.40 to $2.10 \%$ while increasing speed from 40 to $50 \mathrm{rpm}$ increased total losses from 2.10 to $3.60 \%$. On the other hand increasing agitating speed from 20 to $50 \mathrm{rpm}$ decreased specific energy from 31.61 to $28.12 \mathrm{~kW} . \mathrm{h} \mathrm{Mg}^{-1}$. As to $\mathrm{R}_{3}$, obtained results show that increasing speed 20 to $40 \mathrm{rpm}$ decreased total losses from 7.50 to $5.28 \%$. While, increasing speed from 40 to $50 \mathrm{rpm}$ increased total losses from 5.28 to $6.90 \%$.



Fig. (5): Effect of steering speed on total losses and specific energy.

While results show that increasing speed from 20 to $50 \mathrm{rpm}$ decreased specific energy from 46.82 to $33.26 \mathrm{~kW}$.h. $\mathrm{Mg}^{-1}$ under the same previous conditions. Higher values of mechanical agitator speed more than the optimum value tend to increase total losses due to volatility of some parts toward vapor outlet. On the other side, lower values of steering speed less than the optimum value tend to increase total losses because of the increase in parts that had not been cooked. The specific energy decreased by increasing steering speed due to the increase in cooker productivity.

\subsection{Influence of agitating speed on operational and criterion costs at} different kinds of poultry abattoir residues:

Representative values of operational and criterion costs versus agitating speed at different kinds of poultry abattoir residues is given in Fig. 6. With 
respect to $\mathrm{R}_{1}$, obtained results show that increasing speed from 20 to $50 \mathrm{rpm}$ decreasing operational cost from 580 to 490 L.E. $\mathrm{Mg}^{-1}$. Also, obtained results show that increasing speed from 20 to $30 \mathrm{rpm}$ decreasing criterion cost from 3130 to 2650 L.E. $\mathrm{Mg}^{-1}$ while increasing agitating speed from 30 to $50 \mathrm{rpm}$ increasing criterion cost from 2650 to 3100 L.E. $\mathrm{Mg}^{-1}$.

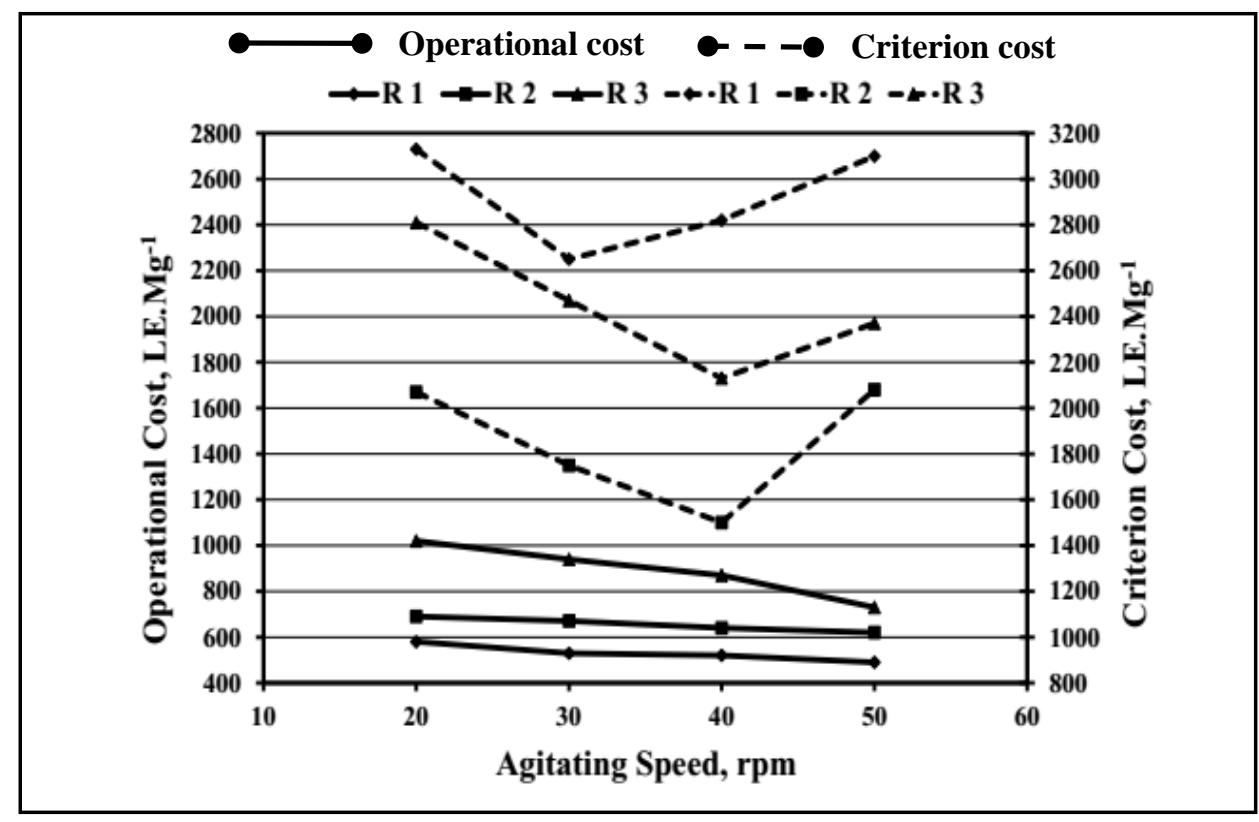

Fig. (6): Effect of agitating speed on operational and criterion costs.

In relation to $R_{2}$, results show that increasing speed from 20 to $50 \mathrm{rpm}$ decreased operational cost from 690 to 620 L.E. $\mathrm{Mg}^{-1}$. Whereas obtained results show that increasing speed 20 to $40 \mathrm{rpm}$ decreased criterion cost from 2070 to 1500 L.E. $\mathrm{Mg}^{-1}$ while increasing speed from 40 to $50 \mathrm{rpm}$ increased criterion cost from 1500 to 2080 L.E. $\mathrm{Mg}^{-1}$. Regarding $\mathrm{R}_{3}$, obtained results show that increasing speed from 20 to $50 \mathrm{rpm}$ decreasing operational cost from 1020 to 730 L.E. $\mathrm{Mg}^{-1}$. On the other hand, results show that increasing speed 20 to $40 \mathrm{rpm}$ decreased criterion cost from 2810 to 2130 L.E. $\mathrm{Mg}^{-1}$ while increasing speed from 40 to $50 \mathrm{rpm}$ increased criterion cost from 2130 to 2370 L.E. $\mathrm{Mg}^{-1}$ under the same previous conditions. The operational cost decreased by increasing mechanical agitator speed due to the increase in cooker productivity. Both higher and lower values of steering speed more or less than the optimum value tend to increase criterion cost due to the increase in total losses during the rendering process. 


\subsection{Influence of different levels of poultry by-product meal on feed} conversion ratio and protein efficiency ratio:

Representative values of growth performance at different levels of poultry by-product meal are shown in Figs. 7 and 8.

\subsubsection{Feed conversion ratio:}

Results of feed conversion ratio, FCR for fish fed on different experimental diets with different replacing percentages of FM by PBM is illustrated in Fig. 7. FCR during the whole experimental period was 1.91 for the experimental diets of $\mathrm{D}_{1}, \mathrm{D}_{2}$ and $\mathrm{D}_{3} ; 1.88$ for $\mathrm{D}_{4}$ and 1.99 for $\mathrm{D}_{5}$, respectively. Analysis of variance show insignificant differences between FCR averages, which indicate that, the replacement of FM in tilapia diets had no any adverse effect on FCR during the period from start to 12 weeks later.

\subsubsection{Protein efficiency ratio:}

Obtained results in Fig. 8. show that during the whole experimental period, relative protein efficiency ratio for the tested diets were $100 \%$ for $D_{1}, D_{2}, D_{3}$ and $\mathrm{D}_{4}$ and $95.68 \%$ for $\mathrm{D}_{5}$, respectively. Results of PER during the whole experimental period refers to the possibility of replacing FM in Tilapia diets with PBM without any adverse effect on PER in order to reduce the feeding costs for this fish species.

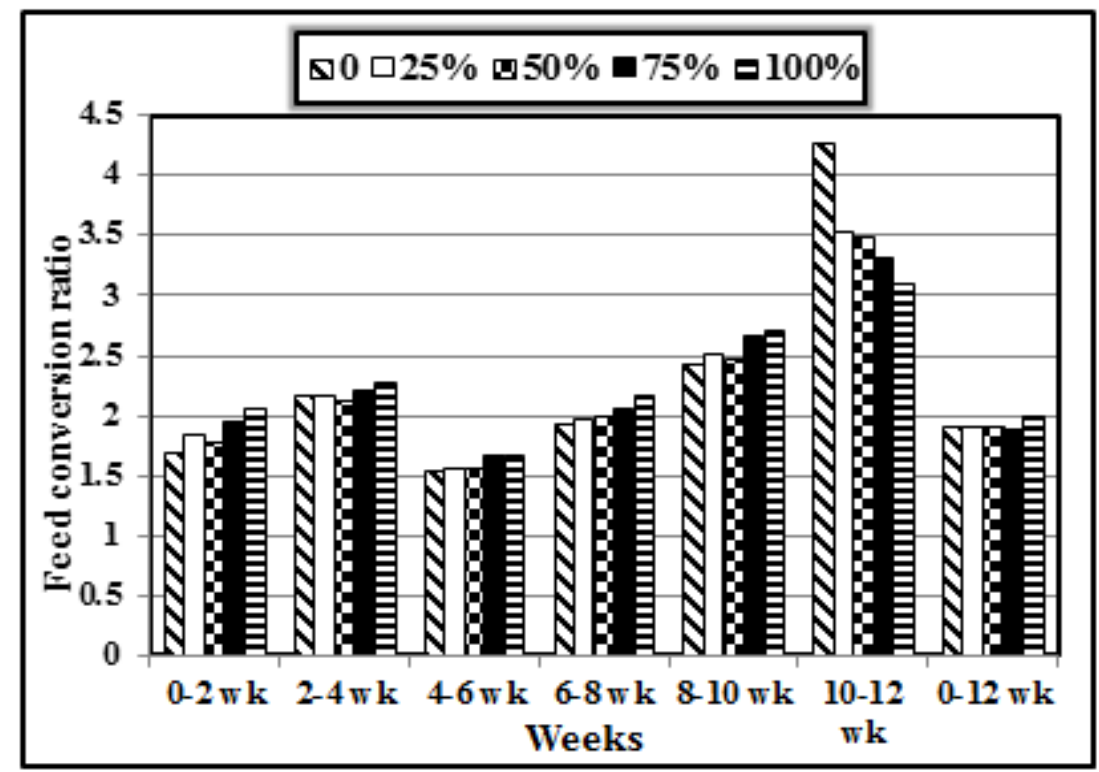

Fig. (7): Effect of partially and totally replacement of FM by PBM on feed conversion ratio. 




Fig. (8): Effect of partially and totally replacement of FM by PBM on Protein efficiency ratio.

\subsection{Economic evaluation:}

Economic evaluation of replacement levels of FM by PBM in the diets outlined in Fig. 9. Economic analysis show that feed cost and feed cost gain were high in the control group than the other groups. Feed cost decreased as inclusion levels of PBM increased. Cost was 6020, 5330, 4640 and 3950 L.E. $\mathrm{Mg}^{-1}$ at fish fed diets contained 25, 50, 75 and 100\% of PBM, respectively compared with those fed the control diet were recorded 6660

L.E. $\mathrm{Mg}^{-1}$. The relative cost per each kilogram weight gain was $100,90.35$, $80.00,70.73$ and $61.51 \%$ at fish fed $\mathrm{D}_{1}, \mathrm{D}_{2}, \mathrm{D}_{3}, \mathrm{D}_{4}$ and $\mathrm{D}_{5}$, respectively.

The present study clearly demonstrated that $50 \%$ of FM could be replaced by PBM in diets for Nile tilapia. The reduced performance for fish was because of amino acid imbalances, as well as a lack of n-3 highly unsaturated fatty acids in the diets containing PBM, Yigit, et al. (2006). However, replacing of FM with PBM protein may need supplementation of some essential amino acid such as lysine, methionine and threonine for well growth performance and body composition of fish. From the economic point of view, the best replacement level of FM with PBM was at $\mathrm{D}_{3}(50 \%)$. This diet achieved the same FCR, PER and lower relative cost per kg gain compared with the 
control diet. Thus, cost will be reduced from 6660 to 5330 L.E. $\mathrm{Mg}^{-1}$ with $20 \%$ reduction in cost.

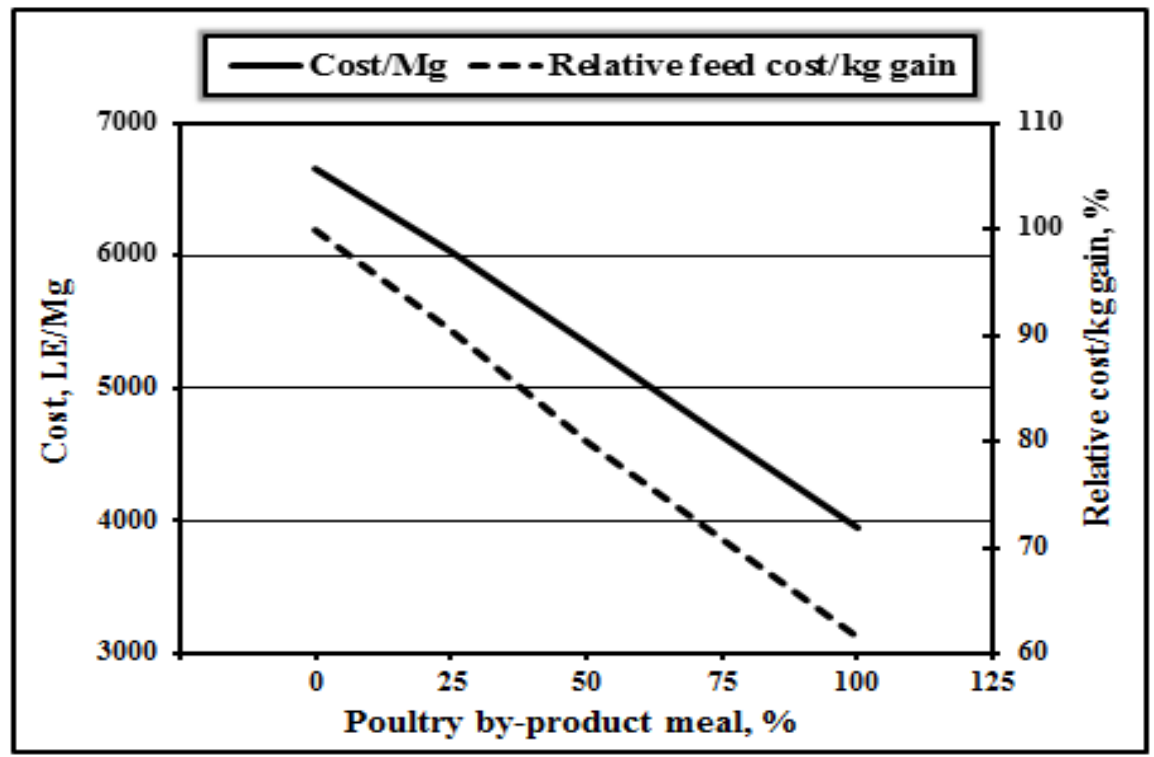

Fig. (9): Economic evaluation of poultry by-products meal.

\section{CONCLUSION}

The first experiment was carried out at Department of Agricultural Engineering, Faculty of Agriculture, Zagazig University to manufacture and evaluate the performance of a batch cooker for rendering poultry abattoir residues. The second experiment was executed at Production and Aquaculture System Department of Central Laboratory for Aquaculture Research (CLAR), Abbassa, Sharkia Governorate to investigate the effect of different levels of poultry by-product meal on the performance and feed utilization for Nile tilapia fish. The experimental results reveal that total losses as well as criterion costs were minimum while overall cooking efficiency was maximum under the operating conditions. The experimental results recommended operating the manufactured cooker at agitating speeds of $30 \mathrm{rpm}$ for $100 \%$ intestines and $40 \mathrm{rpm}$ for $50 \%$ legs $+50 \%$ intestines and $100 \%$ legs at constant vapor pressure of 2 bar. As well as can be feed Nile tilapia fish on diets have from 25 to $50 \%$ of poultry by-product meal. From the economic standpoint, the best replacement level of FM with PBM was at 
D3. This diet achieved the same FCR, PER and lower relative cost compared with the control diet. Hence, feed cost will be reduced from 6660 to 5330 LE. $\mathrm{Mg}^{-1}$ with $20 \%$ reduction.

\section{REFERRENCES}

Pearson, A. M. (1994): Quality Attributes and their Measurement in Meat, Poultry and Fish Products. (C) Springer Science+Business Media Dordrecht. http://www.bseinquiry.gov.uk/files/ib/ibd1/tab11.pdf.

AOACA, (1990): Association of official analytical chemists. The Official Methods of Analyses Association of Official Analytical Chemists International.5th edition, Arlington, VA, USA.

Davis, J. (1989): Low cost extrusion solves wet waste problems. PoultryMisset, 5, (5), Pp: 27-9.

El Boushy, A. R; A. F. B. Poel, Van der and Q. E. D. Walraven, (1990a): Feather meal - a biological waste: Its processing and utilization as a feedstuff for poultry. Biological Wastes, 32, Pp: 39-74.

El Boushy, A. R; A.F.B. Poel, Van der, H. Boer and W.J.J. Gerrits, (1990b): Effect of processing conditions on quality characteristics of feather meal. Internal Report, 199017 9.32. Department of Animal Nutrition, Agricultural University, Wageningen, The Netherlands.

Environmental Protection Agency, EPAA (2002): Abattoirs: air emission control. Retrieved June 19, http://www,epa. nsw.gov. au/mao/ abattoirs, htm.

Expert Group on Animal Feeding Stuffs, EGAFS (1992): Rendering in the United Kingdom (Annex 2.4). Retrieved June 12, 2003, from http://www. bseinquiry.gov.uk/files/ib/ibd1/tab11.pdf

Hertrampf, J. W; and F. P. Pascual (2000): Handbook on ingredients for aquaculture feeds. Kluwer Academic Publishers, 624 pp.

John, G. Ashby (1988): Power Hydraulics. PAVIC Publications. 
Kumar, M. (1989): Handbook of rural technology for the processing of animal by-products. (FAO No. 79). Rome: FAO of the United Nations.

National Research Council, (NRC) (1993): Nutrient requirement of fish. National Academy Press Washington D.C.

Ockerman, H. W., and C. L. Hansen (2000): Animal by-product processing and utilization. Washington, DC: CRC Press LLC.

Ponganeerat J. and T. Watanabe (1991): Nutritive value of protein of feed ingredients for carp Nippon suisam. Gaksishi 57, 503-510.

Prokop, W. H. (1996): The rendering industry-a commitment to public service. In D. A. Franco \& W. Swanson (Eds.), The original recyclers. Joint publishers: The Animal Protein Producers Industry, the Fats \& Proteins Research Foundation, and the National Renderers Association.

Pulsa, A. (1996): Turkistarhat tarvitsevat laadukasta teurasj€atett€a. Lihalehti 3, 38-41, in Finnish.

Steffens, W. (1994): Replacing fish meal with poultry by-product meal in diets for rainbow trout, Aquaculture, 124: 27-34.

Swan, J. E. (1992): Animal by-product processing. In: Hui, Y.H. (Ed.), Encyclopedia Food Science Technology, Vol. 4, Pp: 42-49.

Taylor, D. M. (2000): Inactivation of transmissible degenerative encephalopathy agents: A review. Veterinary Journal, 159 (1), 10-17.

http://www.uk/report/volume13/chapterj.htm

UKDEFRA. (2000): The BSE inquiry report, Vol. 13 industry processes and controls, Ch. 6 rendering, Annex B manufacturing processes of rendering. http://www.bseinquiry.gov.

Yiĝit, M; M. Erdem, S. Koshio, S. Ergun, A. Turker and B. Karaali (2006): Substituting fish meal with poultry by-product meal in diets for black sea turbot Psetta Maeotica, Aquaculture Nutrition, 12: 340347. 


\section{الملخص العربـى}

\section{تصميم وتصنيع وحدة طهى لإنتاج وجبات من مخلفات الدواجن كعلف غير تقليدي

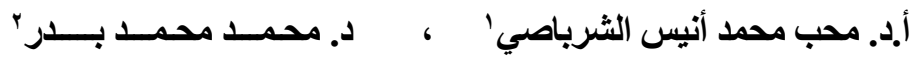

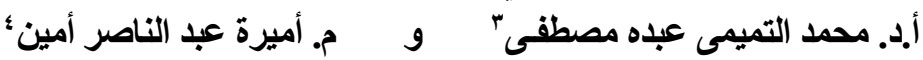


الحيو انية وارتفاع أسعار ها يسبب مشكلة لمربي الأسماك، لذا فقد اتجهت هذه الدراسة إلى إلى إمكانية

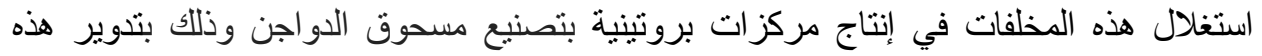
المخلفات مثل (الأحشاء والأرجل) عن طريق معالجتها وتحويلها إلى منتج غذائي آمن ذو فيمة فئه

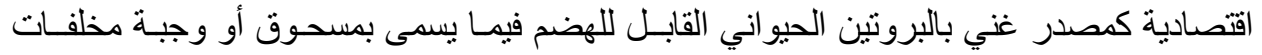

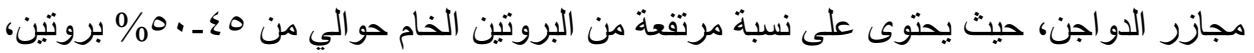

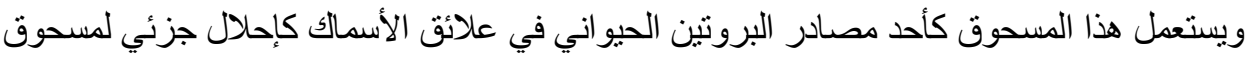

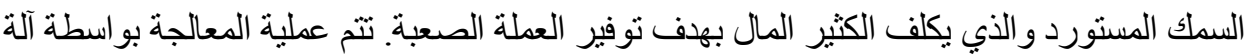
الطبخ عن طريق ضغط البخار مع عملية التقليب المستمر، حيث تتم عملية التعبئة من أعلى مع وجود

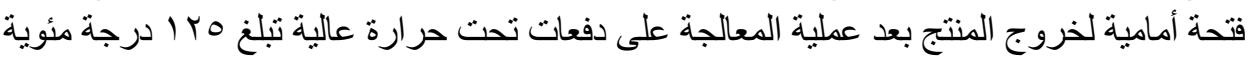

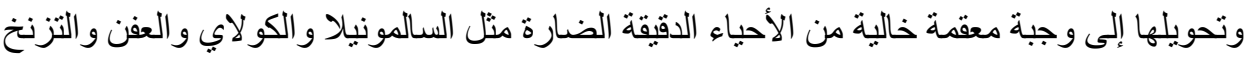

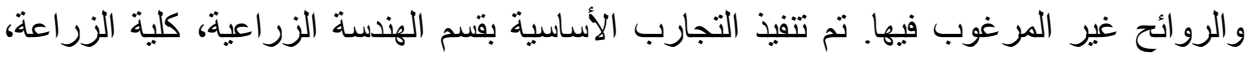
جامعة الزقازيق لتقييم أداء آلة لطهي مخلفات مجازر الدواجن. وقد تم تصنيع الوحدة بإحدى الورش

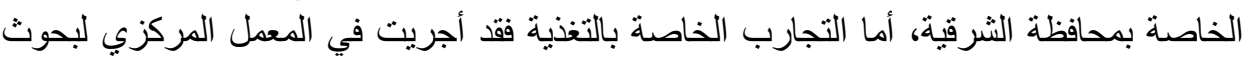
الثروة السمكية، العباسة، أبو حماد، محافظة الشرقية لتقييم تأثثر استبدال مسحوق السمك المستورد

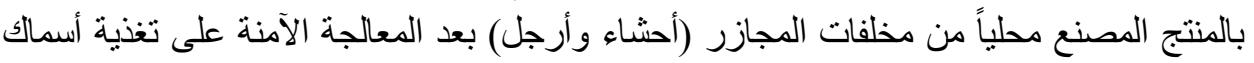
البلطي النيلي، وفيما يلي الأهداف الخاصة بهذي مهذه الدر استة:

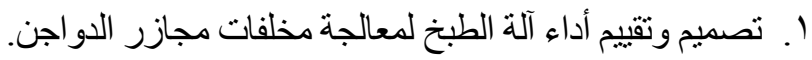

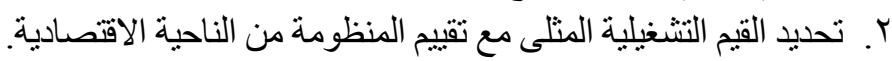
r.. در اسة تأثير استبدال مسحوق السمك بالمنتج المصنع على إنتاج أسماك البلطي. وقد هدفت التجربة الأولى إلى تصميم وتقييم أداء المنظومة المصنعة بأخذ أربع قيم مختلفة لسرعة

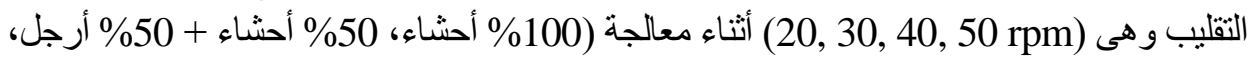
100 أرجل) عند ضغط بخار bar 2 مع أخذ القياسات التالية (الإنتاجية ـ كفاءة الطهي ـ الفواقد الكلية ـ الطاقة المستهلكة وكذا التكاليف الكلية). ومن خلال التجربة الثنانية تم استبدال مسحوق السمك بمسحوق الدواجن المصنع في العلف بنسب (25,50,75 and 100\%) وتمت دراسة تأثير هذه المستويات على استخدام الأعلاف وتكوين الجسم الكامل لأسماك البلطي النيلي وذلك بدر اسة أداء

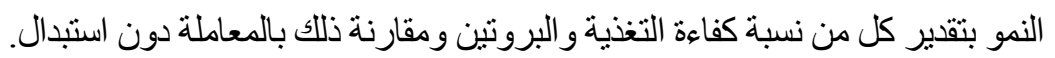

' وكيل الكلية وأستاذ الهندسة الزراعية ـ كلية الزراعة ـ جامعة دمياط ـ مصر.

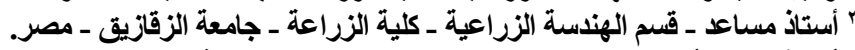

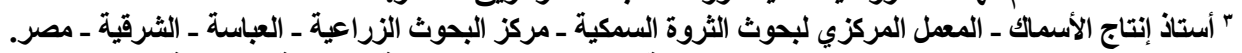

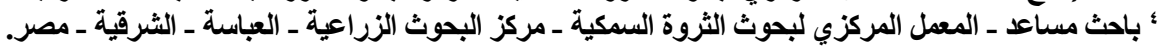


وقد أظهرت النتائج المتحصل عليها أثناء معالجة المخلف الأول (100\% أحشاء) بلغت إنتاجية الآلة (60.30, 50.50 and 37.10 kg.h

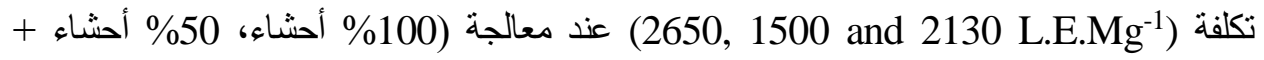



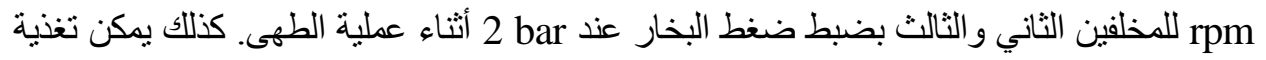

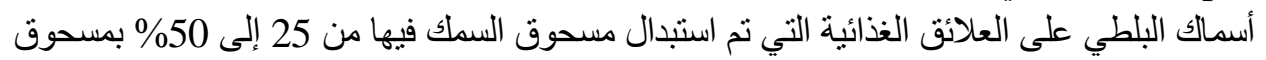

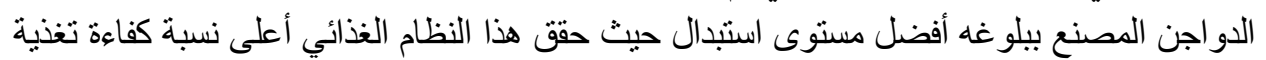

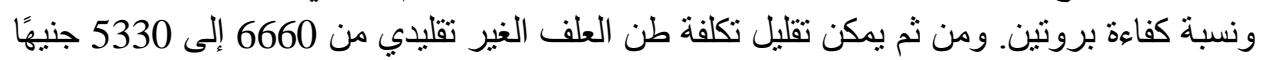
بنسبة 20\% توفير باستخدام مسحوق الدو اجن المصنع مقارنة مع النظام التقليدي دون الاستبدال. 